Do Minimum Wages Reduce Employment? A Case Study of California, 1987-89

\title{
David Card
}

Industrial and Labor Relations Review, Vol. 46, No. 1. (Oct., 1992), pp. 38-54.

Stable URL:

http://links.jstor.org/sici?sici=0019-7939\%28199210\%2946\%3A1\%3C38\%3ADMWREA\%3E2.0.CO\%3B2-\%23

Industrial and Labor Relations Review is currently published by Cornell University, School of Industrial \& Labor Relations.

Your use of the JSTOR archive indicates your acceptance of JSTOR's Terms and Conditions of Use, available at

http://www.jstor.org/about/terms.html. JSTOR's Terms and Conditions of Use provides, in part, that unless you have obtained prior permission, you may not download an entire issue of a journal or multiple copies of articles, and you may use content in the JSTOR archive only for your personal, non-commercial use.

Please contact the publisher regarding any further use of this work. Publisher contact information may be obtained at http://www.jstor.org/journals/cschool.html.

Each copy of any part of a JSTOR transmission must contain the same copyright notice that appears on the screen or printed page of such transmission.

The JSTOR Archive is a trusted digital repository providing for long-term preservation and access to leading academic journals and scholarly literature from around the world. The Archive is supported by libraries, scholarly societies, publishers, and foundations. It is an initiative of JSTOR, a not-for-profit organization with a mission to help the scholarly community take advantage of advances in technology. For more information regarding JSTOR, please contact support@jstor.org. 


\title{
DO MINIMUM WAGES REDUCE EMPLOYMENT?
} A CASE STUDY OF GALIFORNIA, 1987-89

\author{
DAVID CARD*
}

\begin{abstract}
In July 1988, California's minimum wage rose from $\$ 3.35$ to $\$ 4.25$. During the previous year, $11 \%$ of workers in the state and $50 \%$ of California teenagers had earned less than the new state minimum. Using published data and samples from the Current Population Survey, the author compares changes in the labor market outcomes of California workers to the corresponding changes in a group of states with no increase in the minimum wage. The minimum wage increase raised the earnings of low-wage workers by $5-10 \%$. Contrary to conventional predictions, however, there was no decline in teenage employment, or any relative loss of jobs in retail trade.
\end{abstract}

$F^{2}$ Ew substantive issues generate as much agreement among economists as the effects of minimum wage legislation. It is widely believed that the imposition of a binding wage floor will reduce the employment of younger and less-skilled workers. Although the theoretical arguments underlying this consensus are simple and compelling, the empirical evidence is surprisingly limited (see Brown, Gilroy, and Kohen 1982 for a comprehensive survey). A major obstacle confronting most recent studies of minimum wage legislation is the near-universality of the federal minimum rate. Despite some specific exceptions in the law, the vast majority of workers are covered by the same wage floor. ${ }^{1}$ Since the federal law is

* The author is Professor of Economics at Princeton University. He thanks Orley Ashenfelter, Henry Farber, Randall Filer, Alan Krueger, George Neumann, Albert Rees, and seminar participants at MIT, Georgetown, and Johns Hopkins for comments and suggestions. The computer programs used in the preparation of this paper are available on request from David Card at the Department of Economics, Princeton University, Princeton, NJ 08544.

${ }^{1}$ At present, roughly $85 \%$ of workers are covered adjusted infrequently, the number of independent observations on the effect of the minimum wage is small.

In the late 1980s, however, several states responded to the decade-long decline in the real value of the federal minimum wage by establishing wage floors above the federal rate. These state-specific increases provide a valuable opportunity to study the effects of minimum wage legislation. As in a conventional non-experimental program evaluation, labor market trends in other states can be used to infer what would have happened to employment, wages, and unemployment in the absence of the law. A similar "treatment and control group" methodology was used in many early studies of the minimum wage (see Lester 1946, for example), but fell out of favor as the coverage of the federal minimum expanded and longer time series of aggregate data became available.

Among the states that raised their

by the federal law. In addition, many states have historically maintained state minimums equal to the federal rate for workers outside the federal law. See Questor (1981). 
minimum rates, California enacted the most notable change. In July 1988 California's minimum wage increased from $\$ 3.35$ (the prevailing federal rate) to $\$ 4.25$ per hour. In the previous year $11 \%$ of all workers in the state and $50 \%$ of California teenagers earned between $\$ 3.35$ and $\$ 4.24$ per hour. Furthermore, the California law applied very broadly, extending even to tipped employees in retail trade. Estimates presented by Brown, Gilroy, and Kohen (1982) suggest that teenage employment would fall by $3-8 \%$ in response to the rise in the minimum wage.

This paper uses data from the Current Population Survey (CPS) and other sources to measure the effects of the increase in the California minimum wage. The available CPS samples are large: about 20,000 individuals of working age and 1,500 teenagers per year. These samples, together with samples of individuals from other states with no change in minimum wage laws, permit fairly precise inferences on the effects of the increased minimum. I tabulate the relative changes in wages, employment, and unemployment for different age-ethnic-education groups and compare the magnitude of these changes to the fraction of the group who earned less than $\$ 4.25$ in the year before the law was enacted. I also devote special attention to two heavily affected groups: teenagers and employees in retail trade.

\section{A Brief History}

The rise in California's minimum wage followed a year-long sequence of legislative, administrative, and judicial decisions. In May 1987, the State Assembly's Labor and Employment Commission voted to raise the minimum from $\$ 3.35$ to $\$ 4.25$ per hour on January 11988 , with further increases in 1989 and 1990. A modified proposal containing a single increase to $\$ 4.25$ was subsequently passed by both houses of the legislature. This bill was vetoed by the governor, who cited the pending decision of the state's Industrial Welfare Commission (IWC). Under California law the IWC is empowered to set minimum wages for workers in the state. The Commission had begun hearings on a new minimum in 1986, and in December 1987 announced an increase in the minimum wage to $\$ 4.25$, effective July 1,1988 .

The IWC also established a subminimum rate of $\$ 3.50$ per hour for tipped employees. Previous California regulations did not permit a tipped subminimum, and the new provision was immediately appealed by the California Labor Federation. An appellate court panel ruled against the subminimum in June 1988. The July 1 effective date therefore passed amid confusion as to the actual minimum wage for tipped employees. The issue was resolved four months later when the State Supreme Court upheld the lower court and rejected the subminimum provision. By the end of 1988 the $\$ 4.25$ minimum rate was clearly established for most workers in the state, with minor exemptions for a few specific occupations and employees under 18 years of age (who faced a $\$ 3.60$ minimum).

\section{Characteristics of Low-Wage Workers in 1987}

Table 1 presents information on various wage groups in California in the year before the new minimum. The data are based on a one-quarter sample of the 12 monthly CPS surveys conducted during 1987. (The samples are described in an appendix to the unpublished version of this paper-Card 1991.) Each month, wage earners in two of the eight rotation groups in the CPS are asked to report the usual hours and usual hourly or weekly earnings on their main job. For individuals who report weekly earnings I have constructed an hourly wage by dividing usual weekly earnings by usual weekly hours. ${ }^{2}$ Workers are then sorted into categories depending on the value of their actual or imputed hourly wage.

In $1987,1.3 \%$ of California workers

\footnotetext{
${ }^{2}$ I ignore the wages of individuals whose wage or earnings responses are imputed by the Census Bureau.
} 
Table 1. Characteristics of California Wage and Salary Earners, 1987.

\begin{tabular}{|c|c|c|c|}
\hline \multirow[b]{2}{*}{ Characteristic } & \multirow[b]{2}{*}{ All Earners } & \multicolumn{2}{|c|}{ Earners with Hourly Wage: } \\
\hline & & $<\$ 3.35$ & $\$ 3.35-4.24$ \\
\hline 1. Average Hourly Wage ( $\$ /$ hour) & $\begin{array}{l}10.69 \\
(0.06)\end{array}$ & $\begin{array}{c}2.64 \\
(0.05)\end{array}$ & $\begin{array}{c}3.70 \\
(0.01)\end{array}$ \\
\hline 2. Usual Hours Per Week & $\begin{array}{c}38.5 \\
(0.1)\end{array}$ & $\begin{array}{c}36.9 \\
(1.9)\end{array}$ & $\begin{array}{c}30.7 \\
(0.4)\end{array}$ \\
\hline 3. Usual Weekly Earnings (\$/week) & $\begin{array}{r}426.3 \\
(2.8)\end{array}$ & $\begin{array}{l}97.9 \\
(5.4)\end{array}$ & $\begin{array}{r}114.3 \\
(1.4)\end{array}$ \\
\hline 4. Average Age (years) & 35.3 & 31.9 & 27.7 \\
\hline 5. Percent Age 16-19 & 6.4 & 26.2 & 31.0 \\
\hline 6. Percent Age 20-24 & 14.1 & 14.7 & 23.0 \\
\hline 7. Percent Enrolled (of those age 16-24) & 30.1 & 41.8 & 47.0 \\
\hline $\begin{array}{l}\text { 8. Ethnicity }(\%) \\
\text { a. Hispanic } \\
\text { b. Black Non-Hispanic } \\
\text { c. White Non-Hispanic }\end{array}$ & $\begin{array}{r}22.5 \\
6.1 \\
62.7\end{array}$ & $\begin{array}{r}36.8 \\
4.1 \\
45.2\end{array}$ & $\begin{array}{r}39.0 \\
4.6 \\
46.6\end{array}$ \\
\hline 9. Percent Female & 45.8 & 67.2 & 57.9 \\
\hline 10. Percent in Central City & 37.4 & 47.6 & 39.4 \\
\hline 11. Average Family Income ${ }^{\mathrm{a}}$ (\$/year) & $\begin{array}{r}35,548 \\
(222)\end{array}$ & $\begin{array}{c}24,863 \\
(2,023)\end{array}$ & $\begin{array}{r}24,338 \\
(649)\end{array}$ \\
\hline 12. Percent with Family Income $<\$ 15,000 /$ Year & 19.0 & 48.8 & 44.2 \\
\hline $\begin{array}{l}\text { 13. Industry Distribution (\%) } \\
\text { a. Agriculture } \\
\text { b. Low-wage Manufacturing }{ }^{\mathrm{b}} \\
\text { c. Retail Trade }\end{array}$ & $\begin{array}{r}2.7 \\
2.3 \\
16.7\end{array}$ & $\begin{array}{r}5.4 \\
9.4 \\
21.9\end{array}$ & $\begin{array}{r}7.4 \\
7.3 \\
48.0\end{array}$ \\
\hline 14. Sample Size & 11,591 & 150 & 1,220 \\
\hline
\end{tabular}

Notes: Data are taken from 1987 Current Population Survey. Earners are wage and salary earners age 16-68, excluding self-employed and unpaid workers. Standard errors in parentheses.

${ }^{a}$ Reported interval values are assigned interval means. See text.

b Apparel, textiles, furniture, toys, and sporting goods manufacturing.

earned less than the prevailing federal minimum of $\$ 3.35$ per hour. The characteristics of these workers are reported in column 2 of Table 1. Since California law prescribed a minimum of $\$ 3.35$ for most workers not covered by the federal statute, some of these individuals were presumably working illegally for noncomplying employers. Others, including some 16and 17-year-olds and some live-in household workers, legally earned less than the federal/state minimum. A third group of subminimum-wage earners consists of salaried workers who under-reported their usual weekly earnings or over-reported their usual hours. The importance of this phenomenon is suggested by the fact that salaried workers are three times more likely to report a subminimum wage than hourly rated workers, even though (on average) salaried workers have substan- tially higher earnings than hourly rated workers.

A much larger group of workers $(10.8 \%)$ were paid either exactly $\$ 3.35$ or between $\$ 3.36$ and $\$ 4.24$ per hour. For simplicity, I refer to these as "affected workers," since it is precisely these individuals who would have either lost their jobs or had their wages raised if the new minimum had taken effect in 1987. As shown in row $13 \mathrm{c}$ of the table, about one-half of affected workers were employed in retail trade, with another $15 \%$ in agriculture and low-wage manufacturing industries.

A comparison of the demographic characteristics of all wage earners and those in the affected group suggests that the latter are younger and more likely to be female, Hispanic, and enrolled in school. Over one-half of affected wage earners were 
under age 25. Indeed, in 1987, 52\% of California teenagers and $29 \%$ of those age 20 to 24 reported wages of $\$ 3.35-4.24$ per hour.

The family income data in rows 11 and 12 suggest that the low hourly earnings of affected workers are associated with low family income. The income measure here pertains to the 12 -month period ending 4 months before the CPS interview. ${ }^{3}$ Some $44 \%$ of affected wage earners lived in families with annual incomes less than $\$ 15,000$. By comparison, $24 \%$ of all Californians age $16-68$ and $19 \%$ of employed individuals lived in such families. Despite their relative concentration in the lower tail of the family income distribution, there are still significant numbers of affected workers in high-income families. Any distributional consequences of the rise in the California minimum wage are necessarily modest, although perhaps more favorable than suggested by earlier studies. ${ }^{4}$

\section{Effects on the Wage Distribution}

An immediate question of interest is whether state-specific minimum wage regulations have any effect on the labor market. Even more than is the case for the federal law, the enforcement provisions and penalties for non-compliance with state minimum wage regulations are unclear. Some evidence of an effect of the new law is provided by Figure 1, which plots the fractions of workers earning less than $\$ 3.35$ per hour and between $\$ 3.35$ and $\$ 4.24$ per hour in each quarter from

\footnotetext{
${ }^{3}$ Family income categories are reported on the CPS control card when a household first enters the survey. I have constructed the average income figures in Table 1 by assigning to each interval the mean level of family income in the previous year among currently employed individuals in the March 1988 CPS who report family income in the same interval.

${ }^{4}$ See Gramlich (1976), for example. Two important differences between the 1988 California wage increase and the 1974-75 increases in the federal minimum considered by Gramlich are the much lower incidence of subminimum pay in California in 1988 , and the much wider range of workers affected by the California wage increase.
}

1987-I to 1989-IV. For comparison, the figure also shows the same fractions in a group of states that did not change their minimum wage laws over the 1987-89 period. Ideally, one might have preferred to use neighboring states like Nevada, Oregon, or Washington to form a comparison group for California workers. Following California's lead, however, these states all raised their minimum wage rates in late 1988 or 1989. I have therefore used workers in Arizona, Florida, Georgia, New Mexico, and Dallas-Fort Worth as a comparison group. ${ }^{5}$

The appendix compares the characteristics of workers in California and the other areas. Briefly, the two groups had very similar labor force participation rates, employment-population ratios, and unemployment rates in 1987. The two samples also have roughly comparable gender, age, and education distributions, although the fraction of Hispanic workers is higher in California. Perhaps the biggest difference is in the level of wages, which was $22 \%$ higher in California than in the comparison areas in 1987.

Figure 1 shows a sharp decline in the percentage of California workers earning between $\$ 3.35$ and $\$ 4.24$ per hour after the second quarter of 1988 (that is, after the effective date of the law). The fraction of workers in that wage range in the states without a change in laws shows only a modest downward trend. The relative reduction in California between 1987 and 1989 was 5.2 percentage points. Although not shown in the figure, this change was accompanied by a sharp increase in the percentage of workers reporting exactly $\$ 4.25$ per hour: from $0.4 \%$ in 1987 to $4.2 \%$ in 1989.

In contrast to the effect on the fraction earning \$3.25-4.24 per hour, the increase in the minimum wage had virtually no effect on the fraction earning less than

${ }^{5}$ I have only used Dallas-Fort Worth, rather than all of Texas, for two reasons. First, during the mid-to-late 1980s, economic conditions in many parts of Texas were affected by the slump in oil prices. Second, by including only those Texans in Dallas and Fort Worth, I increased the relative fraction of urban workers in the comparison sample. 


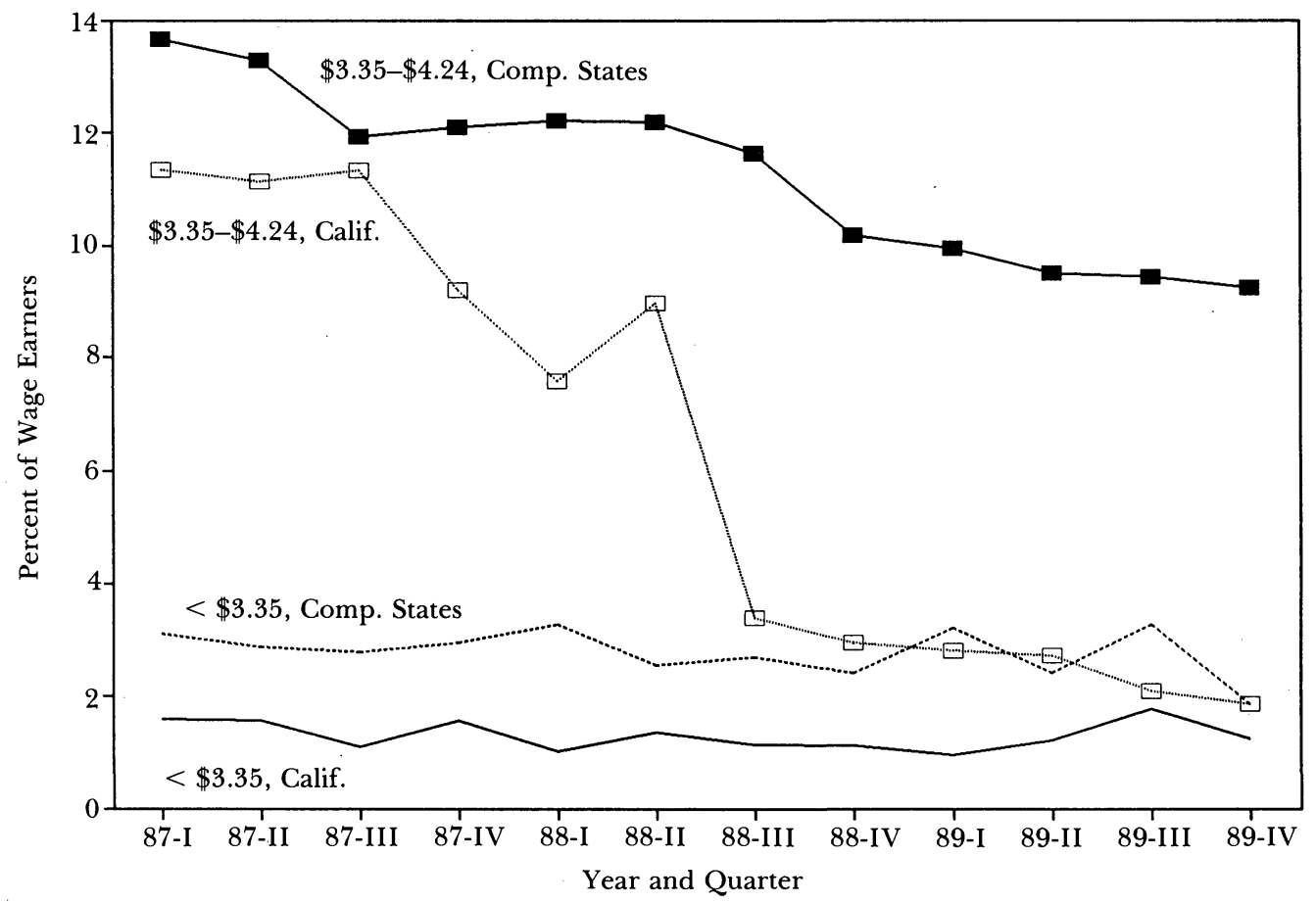

Figure 1. Workers Earning Less Than $\$ 3.35$ per Hour and Between $\$ 3.35$ and $\$ 4.24$ per Hour in California and in Comparison States, 1987-1989.

\$3.35 per hour. This stability implies that the subminimum wage work force (which includes those earning less than $\$ 3.35$ and those earning $\$ 3.35$ to $\$ 4.24$ per hour after July 1988) increased after the effective date of the new law. Using Ashenfelter and Smith's (1979) notion of a noncompliance rate, $31 \%$ of all workers with wage rates less than or equal to the minimum wage in 1987 earned less than the minimum. With the rise in the minimum to $\$ 4.25$, the noncompliance rate rose to $46 \%$.

One potential explanation for this rise is provided by California law, which permits a $15 \%$ lower minimum wage for individuals under 18 years of age and for apprentices and job learners in the first 160 hours of employment. In 1987, the incidence of subminimum pay (less than $\$ 3.35$ per hour) was $9 \%$ among 16- and 17-year-olds; these workers accounted for $15 \%$ of subminimum wage earners. In 1989 the incidence of subminimum pay (less than $\$ 4.25$ ) rose to $17 \%$ among 16- and 17-year-olds. Nevertheless, their share of total subminimum wage employment actually fell to $10 \%$. In fact, the incidence of subminimum pay rose by $200-300 \%$ for most groups in the labor force.

A comparison of wage distributions before and after the new law therefore suggests that the rise in the California minimum wage reduced the fraction of California workers earning \$3.35-4.24 per hour by some 5 percentage points, with little or no effect on the fraction earning less than $\$ 3.35$ per hour. A majority of the affected workers apparently moved to the new minimum wage level. Assuming this to be true, the minimum wage law raised the wage $15 \%$ for $5 \%$ of California workers. This estimate is biased upward by any losses of employment that occurred for workers in the affected wage group (see below). It is biased downward to the extent that some workers with 1987 wages in the affected wage range earned more than $\$ 4.25$ in 1989 , or to the extent that the rise in the minimum affected the earnings of higher-wage workers. 


\section{Effects on Employment}

A first indication of the employment effects of the rise in the minimum wage comes from a comparison of employment and unemployment trends in California and the country as a whole. From 1987 to 1989 the unemployment rate in California fell from $5.8 \%$ to $5.1 \%$. Over the same period the national rate fell from $6.2 \%$ to $5.3 \%$. These trends suggest that economic growth in California was similar to or slightly slower than that elsewhere in the United States. The same conclusion emerges from an analysis of the overall employment-population ratio, which gained 1.1 percentage points in California between 1987 and 1989, compared with 1.5 percentage points nationwide.

For California teenagers, however, the pattern is quite different. Between 1987 and 1989 teenage unemployment rates in California fell 3 percentage points (from $16.9 \%$ to $13.9 \%$ ), while the average U.S. rate fell only 1.9 percentage points (from $16.9 \%$ to $15.0 \%$ ). An even stronger relative trend is indicated by the teenage employment-population ratio, which increased 4.1 percentage points in California (from $43.0 \%$ to $47.1 \%$ ) compared to a 2 percentage point increase nationwide (from $45.4 \%$ to $47.5 \%$ ). Since teenagers are the group most directly affected by an increase in the minimum wage, these responses are clearly unexpected.

I have also used published Bureau of Labor Statistics data to evaluate changes in the employment/population ratio of California workers relative to workers in the comparison sample of Arizona, Florida, Georgia, New Mexico, and Dallas-Fort Worth, Texas. ${ }^{6}$ Data for 1985-90 are presented in Table 2. The pre-1987 data allow a simple check on the validity of the comparison sample as a "control group" for California. If the comparison sample is a legitimate control group, there should be no trend in the pre-1987 gap between

${ }^{6}$ An important advantage of the published data is that they are derived from the full CPS sample in each month, rather than the $1 / 4$ sample used in the rest of this paper.
California and the comparison sample. This specification test is clearly satisfied for both the overall employment rate and the teenage rate. ${ }^{7}$

Between 1987 and 1989, the gap in the overall employment-population ratio between California and the comparison states increased six-tenths of a percentage point, which may account for up to a percentage point of excess teenage employment growth in California relative to the comparison states. ${ }^{8}$ The actual relative increase in teenage employment from 1987 to 1989 was 4.1 percentage points, however, suggesting a gain in employment following the rise in the minimum wage. The data for 1990 show a return to the earlier patterns, although this year marked the onset of a recession (which was particularly severe in California) and a rise in the federal minimum wage to $\$ 3.80$ (on April 1).

The figures in Table 3, derived from CPS microdata, show the effects of the minimum wage on more narrowly defined age-ethnic-education groups. The groups have been selected to yield at least 400 observations per year in California. The first column of the table gives the fraction of workers in each group who earned between $\$ 3.35$ and $\$ 4.24$ in 1987 . This measure of the potential impact of the rise in the minimum wage ranges from $1 \%$ for white college graduates to $50 \%$ for the two teenage groups (white non-Hispanics and Hispanics). The next columns contain the means of three labor market outcomes in 1987: average hourly earnings, the employment-population rate, and the unemployment rate. Finally, the last three columns give the changes in these outcomes between 1987 and 1989 in California relative to the corresponding changes

\footnotetext{
${ }^{7}$ If the comparison sample is expanded to include all of Texas, the gap between the overall employment-population ratio in California and the comparison states shows less stability over the 1985-90 period, although the gap in teenage employment rates still drops 3-4 percentage points after 1987.

${ }^{8}$ As noted in my other article in this issue (Table 3 ), teenage employment in a state normally responds to aggregate employment in the state with a coefficient slightly greater than 1 .
} 
Table 2. Employment-Population Ratios for Teenagers and All Workers: California Versus Comparison Areas, 1985-1990.

(Standard Errors in Parentheses)

\begin{tabular}{lcccccc}
\hline & \multicolumn{5}{c}{ Employment-Population Ratio (Percent) } \\
\cline { 2 - 7 } Sample & 1985 & 1986 & 1987 & 1988 & 1989 & 1990 \\
\hline All Age 16+: & & & & & \\
California & 61.3 & 62.0 & 63.1 & 63.8 & 64.2 & 63.1 \\
& $(0.4)$ & $(0.4)$ & $(0.4)$ & $(0.4)$ & $(0.4)$ & $(0.4)$ \\
Comparisons & 59.9 & 60.9 & 61.7 & 62.4 & 62.2 & 62.2 \\
& $(0.3)$ & $(0.3)$ & $(0.3)$ & $(0.3)$ & $(0.3)$ & $(0.3)$ \\
California - Comparisons & 1.4 & 1.1 & 1.4 & 1.4 & 2.0 & 0.9 \\
& $(0.5)$ & $(0.5)$ & $(0.5)$ & $(0.5)$ & $(0.5)$ & $(0.5)$ \\
Teenagers: & & & & & 47.1 & 41.4 \\
California & 41.0 & 41.2 & 43.0 & 47.1 & 47.1 & $(1.3)$ \\
& $(1.3)$ & $(1.3)$ & $(1.3)$ & $(1.3)$ & $(1.3)$ & 45.2 \\
Comparisons & 45.7 & 47.0 & 47.0 & 46.5 & 47.0 & $(1.2)$ \\
California & $(1.2)$ & $(1.2)$ & $(1.2)$ & $(1.2)$ & $(1.2)$ & -3.8 \\
& -4.7 & -5.8 & -4.0 & 0.6 & 0.1 & $(1.8)$ \\
\hline
\end{tabular}

Notes: Employment-population ratios are taken from U.S. Department of Labor, Bureau of Labor Statistics, "Geographic Profiles of Employment and Unemployment," 1985-1990 editions. Data for comparison areas are a weighted average of data for Arizona, Florida, Georgia, New Mexico, and Dallas-Fort Worth, using 1988 population counts as weights. Standard errors are based on published sampling errors for 1989.

for the same groups in the comparison states. ${ }^{9}$ These simple "differences-indifferences" measure the excess changes that occurred in California as a result of the rise in the minimum wage (or other unspecified factors).

Among the 15 groups in the table, only white and Hispanic teenagers and 20-24year-old Hispanics show significantly different relative wage growth in California and the comparison areas. As might be expected, these three groups enjoyed substantial relative wage gains in California. More difficult to explain are the relative increases in employment for the three groups.

Although the differences-in-differences in Table 3 are imprecise, one can ask whether there is any systematic relation between the fraction of a group earning \$3.35-4.24 per hour in 1987 and the relative changes in the labor market outcomes for that group. The answer for wages is yes: a simple (unweighted) regres-

\footnotetext{
${ }^{9}$ Owing to the low number of Asians outside California, the sample sizes of the "other nonHispanics” groups are too small for a meaningful analysis in the comparison sample.
}

sion of the difference-in-differences of wages on the fraction of workers in the group earning $\$ 3.35$ to $\$ 4.24$ per hour in 1987 yields a coefficient of 0.32 , with a standard error of $0.10 .{ }^{10}$ The magnitude of this coefficient suggests that the rise in the minimum wage did more than simply "top up" the wages of those who would have earned between $\$ 3.35$ and $\$ 4.25$ in the absence of the law (each of whom would receive a $15 \%$ wage increase, on average, leading to a coefficient of 0.15 ). One explanation is that concern over relative wages leads to a "spillover" effect for workers who previously earned more than the new minimum (see Grossman [1983] for an earlier analysis). Given the imprecision of the wage data, however, it is difficult to test this hypothesis more carefully.

In contrast to conventional predictions, groups with a higher fraction of low-wage workers do not appear to have suffered any relative losses in employment. Indeed, the correlation between the difference-in-

${ }^{10}$ The R-squared of the regression is 0.44 . The only significant outlier is the group of 16-24-yearold blacks. 
Table 3. Wages, Employment, and Unemployment Rates for Various Groups: California, 1987, and California - Comparisons, 1987 to 1989.

(Standard Errors in Parentheses)

\begin{tabular}{|c|c|c|c|c|c|c|c|}
\hline \multirow[b]{2}{*}{ Group } & \multicolumn{4}{|c|}{ California, 1987} & \multicolumn{3}{|c|}{ Differences-in-Differences ${ }^{\mathrm{a}}$} \\
\hline & $\begin{array}{c}\text { Percent } \\
\$ 3.35-4.24\end{array}$ & $\begin{array}{l}\text { Mean } \\
\text { Wage }\end{array}$ & $\begin{array}{l}\text { Employm. } \\
\text { Rate }\end{array}$ & $\begin{array}{l}\text { Unemp. } \\
\text { Rate }\end{array}$ & $\begin{array}{l}\text { Mean } \\
\text { Wage }\end{array}$ & $\begin{array}{l}\text { Employm. } \\
\text { Rate }\end{array}$ & $\begin{array}{l}\text { Unemp. } \\
\text { Rate }\end{array}$ \\
\hline $\begin{array}{l}\text { White Non-Hispar } \\
\text { Age } 16-19\end{array}$ & 52.1 & $\begin{array}{c}4.69 \\
(0.10)\end{array}$ & $\begin{array}{l}48.2 \\
(1.5)\end{array}$ & $\begin{array}{l}13.9 \\
(1.4)\end{array}$ & $\begin{array}{c}9.6 \\
(4.3)\end{array}$ & $\begin{array}{c}5.9 \\
(3.1)\end{array}$ & $\begin{array}{c}0.2 \\
(2.6)\end{array}$ \\
\hline $\begin{array}{l}\text { Age } 20-24, \\
\text { Educ. } \leq 12\end{array}$ & 13.8 & $\begin{array}{c}7.65 \\
(0.19)\end{array}$ & $\begin{array}{l}73.5 \\
(1.6)\end{array}$ & $\begin{array}{c}7.9 \\
(1.1)\end{array}$ & $\begin{array}{c}1.3 \\
(5.8)\end{array}$ & $\begin{array}{l}-0.9 \\
(3.2)\end{array}$ & $\begin{array}{r}-0.7 \\
(2.2)\end{array}$ \\
\hline $\begin{array}{l}\text { Age } 20-24, \\
\quad \text { Educ. }>12\end{array}$ & 14.0 & $\begin{array}{c}7.53 \\
(0.16)\end{array}$ & $\begin{array}{l}77.0 \\
(1.6)\end{array}$ & $\begin{array}{c}5.0 \\
(0.9)\end{array}$ & $\begin{array}{c}0.7 \\
(4.8)\end{array}$ & $\begin{array}{c}2.0 \\
(3.1)\end{array}$ & $\begin{array}{c}-0.6 \\
(1.8)\end{array}$ \\
\hline $\begin{array}{l}\text { Age } 25+, \\
\quad \text { Educ. }<12\end{array}$ & 14.6 & $\begin{array}{c}9.17 \\
(0.28)\end{array}$ & $\begin{array}{l}46.3 \\
(1.5)\end{array}$ & $\begin{array}{c}9.3 \\
(1.2)\end{array}$ & $\begin{array}{c}9.5 \\
(7.0)\end{array}$ & $\begin{array}{l}-2.3 \\
(2.8)\end{array}$ & $\begin{array}{c}-3.7 \\
(1.9)\end{array}$ \\
\hline $\begin{array}{l}\text { Age } 25+, \\
\quad \text { Educ. }=12\end{array}$ & 4.5 & $\begin{array}{l}10.77 \\
(0.13)\end{array}$ & $\begin{array}{l}65.7 \\
(0.8)\end{array}$ & $\begin{array}{c}4.2 \\
(0.4)\end{array}$ & $\begin{array}{l}-2.3 \\
(2.4)\end{array}$ & $\begin{array}{c}1.4 \\
(1.4)\end{array}$ & $\begin{array}{c}-0.3 \\
(0.7)\end{array}$ \\
\hline $\begin{array}{l}\text { Age } 25+, \\
\quad \text { Some College }\end{array}$ & 3.2 & $\begin{array}{l}12.35 \\
(0.14)\end{array}$ & $\begin{array}{l}75.1 \\
(0.8)\end{array}$ & $\begin{array}{c}3.3 \\
(0.4)\end{array}$ & $\begin{array}{l}-0.3 \\
(2.5)\end{array}$ & $\begin{array}{l}-0.4 \\
(1.5)\end{array}$ & $\begin{array}{r}-0.3 \\
(0.7)\end{array}$ \\
\hline $\begin{array}{l}\text { Age } 25+ \\
\text { Educ. } \geq 16\end{array}$ & 1.0 & $\begin{array}{l}16.45 \\
(0.18)\end{array}$ & $\begin{array}{l}83.4 \\
(0.6)\end{array}$ & $\begin{array}{c}2.3 \\
(0.3)\end{array}$ & $\begin{array}{c}0.5 \\
(2.4)\end{array}$ & $\begin{array}{c}0.5 \\
(1.2)\end{array}$ & $\begin{array}{r}-0.8 \\
(0.5)\end{array}$ \\
\hline \multicolumn{8}{|c|}{ Black Non-Hispanics: } \\
\hline Age $16-24$ & 27.0 & $\begin{array}{c}6.93 \\
(0.37)\end{array}$ & $\begin{array}{l}46.9 \\
(2.6)\end{array}$ & $\begin{array}{l}21.7 \\
(2.8)\end{array}$ & $\begin{array}{l}-8.6 \\
(8.4)\end{array}$ & $\begin{array}{c}-0.8 \\
(5.0)\end{array}$ & $\begin{array}{c}1.5 \\
(5.4)\end{array}$ \\
\hline $\begin{array}{l}\text { Age } 25+ \\
\text { Educ. } \leq 12\end{array}$ & 6.8 & $\begin{array}{c}9.53 \\
(0.29)\end{array}$ & $\begin{array}{l}53.5 \\
(2.1)\end{array}$ & $\begin{array}{l}10.1 \\
(1.6)\end{array}$ & $\begin{array}{l}-2.9 \\
(5.1)\end{array}$ & $\begin{array}{c}4.5 \\
(3.5)\end{array}$ & $\begin{array}{c}-1.2 \\
(2.6)\end{array}$ \\
\hline $\begin{array}{l}\text { Age } 25+, \\
\quad \text { Educ. }>12\end{array}$ & 1.4 & $\begin{array}{l}12.35 \\
(0.33)\end{array}$ & $\begin{array}{l}79.4 \\
(1.7)\end{array}$ & $\begin{array}{c}6.4 \\
(1.1)\end{array}$ & $\begin{array}{c}2.7 \\
(6.1)\end{array}$ & $\begin{array}{c}5.7 \\
(3.1)\end{array}$ & $\begin{array}{r}-2.5 \\
(1.9)\end{array}$ \\
\hline \multicolumn{8}{|l|}{ Hispanics: } \\
\hline Age 16-19 & 52.6 & $\begin{array}{c}4.36 \\
(0.11)\end{array}$ & $\begin{array}{l}37.7 \\
(2.1)\end{array}$ & $\begin{array}{l}21.4 \\
(2.6)\end{array}$ & $\begin{array}{l}23.1 \\
(8.6)\end{array}$ & $\begin{array}{c}5.8 \\
(4.8)\end{array}$ & $\begin{array}{r}-4.9 \\
(5.4)\end{array}$ \\
\hline Age 20-24 & 26.2 & $\begin{array}{c}5.87 \\
(0.12)\end{array}$ & $\begin{array}{l}69.8 \\
(1.8)\end{array}$ & $\begin{array}{l}10.3 \\
(1.3)\end{array}$ & $\begin{array}{l}12.4 \\
(5.3)\end{array}$ & $\begin{array}{c}1.2 \\
(3.9)\end{array}$ & $\begin{array}{c}1.4 \\
(2.9)\end{array}$ \\
\hline $\begin{array}{l}\text { Age } 25+, \\
\text { Educ. }<12\end{array}$ & 22.9 & $\begin{array}{c}6.49 \\
(0.11)\end{array}$ & $\begin{array}{l}61.3 \\
(1.2)\end{array}$ & $\begin{array}{c}8.5 \\
(0.8)\end{array}$ & $\begin{array}{c}3.3 \\
(5.5)\end{array}$ & $\begin{array}{c}-0.1 \\
(2.8)\end{array}$ & $\begin{array}{c}-0.7 \\
(2.1)\end{array}$ \\
\hline $\begin{array}{l}\text { Age } 25+, \\
\quad \text { Educ. }=12\end{array}$ & 7.8 & $\begin{array}{l}8.67 \\
(0.18)\end{array}$ & $\begin{array}{l}71.7 \\
(1.5)\end{array}$ & $\begin{array}{c}6.1 \\
(0.9)\end{array}$ & $\begin{array}{c}4.1 \\
(4.8)\end{array}$ & $\begin{array}{c}3.5 \\
(3.1)\end{array}$ & $\begin{array}{r}-1.8 \\
(1.9)\end{array}$ \\
\hline $\begin{array}{l}\text { Age } 25+, \\
\quad \text { Educ. }>12\end{array}$ & 3.5 & $\begin{array}{l}12.20 \\
(0.30)\end{array}$ & $\begin{array}{l}82.6 \\
(1.5)\end{array}$ & $\begin{array}{c}4.2 \\
(0.8)\end{array}$ & $\begin{array}{l}-7.0 \\
(5.3)\end{array}$ & $\begin{array}{c}3.6 \\
(2.9)\end{array}$ & $\begin{array}{r}-1.8 \\
(1.6)\end{array}$ \\
\hline \multicolumn{8}{|c|}{ Other Non-Hispanics: } \\
\hline Age $16-24$ & 23.7 & $\begin{array}{c}6.10 \\
(0.23)\end{array}$ & $\begin{array}{l}48.8 \\
(2.3)\end{array}$ & $\begin{array}{l}10.5 \\
(1.9)\end{array}$ & - & - & - \\
\hline $\begin{array}{l}\text { Age } 25+ \\
\quad \text { Educ. } \leq 12\end{array}$ & 21.1 & $\begin{array}{c}7.44 \\
(0.24)\end{array}$ & $\begin{array}{l}58.6 \\
(1.9)\end{array}$ & $\begin{array}{c}4.9 \\
(1.1)\end{array}$ & - & - & - \\
\hline $\begin{array}{l}\text { Age } 25+ \\
\quad \text { Educ. }>12\end{array}$ & 3.1 & $\begin{array}{l}13.04 \\
(0.28)\end{array}$ & $\begin{array}{l}81.2 \\
(1.2)\end{array}$ & $\begin{array}{c}3.2 \\
(0.6)\end{array}$ & - & - & - \\
\hline $\begin{array}{l}\text { All } \\
\qquad \text { (Age 16-68) }\end{array}$ & 10.8 & $\begin{array}{l}10.69 \\
(0.06)\end{array}$ & $\begin{array}{l}68.4 \\
(0.3)\end{array}$ & $\begin{array}{c}5.8 \\
(0.2)\end{array}$ & $\begin{array}{l}-1.8 \\
(1.2)\end{array}$ & $\begin{array}{c}0.8 \\
(0.6)\end{array}$ & $\begin{array}{r}-0.6 \\
(0.4)\end{array}$ \\
\hline
\end{tabular}

Note: "Other Non-Hispanics" include Asians and Native Americans.

${ }^{a}$ Change between 1987 and 1989 for outcome in California minus corresponding change for outcome in comparison areas. The difference-in-differences of mean wages represents the difference in percentage changes of mean wages. 
differences in employment rates and the fraction of workers earning \$3.34-4.25 in 1987 is 0.3 . This positive correlation is due to the large increases in relative employment registered by the two teenage groups. These comparisons thus confirm the conclusion from the published data in Table 2: the rise in the minimum raised the wages of low-wage workers, with no evidence of adverse employment effects.

\section{Effects of the California Minimum Wage on Teenagers}

In light of the findings in Tables 2 and 3 , in this section I present a more detailed analysis of the experiences of 16-19-yearold workers in California and the comparison areas. Table 4 presents 1987 and 1989 data for teenagers in California and the comparison areas together with the differences-in-differences of the various labor market outcomes. The first three rows of the table give information on the wage distributions of teenage workers. The fraction of California teenagers earning \$3.35-4.24 per hour declined dramatically between 1987 and 1989. Much of this change was associated with a reduction in the number of workers earning the old minimum wage and a corresponding increase in the number earning the new minimum rate.

These relative changes were associated with a $10 \%$ relative increase in mean wages for California teenagers. Hours per week of employed teenagers also increased slightly in California relative to the comparison group, leading to an $11 \%$ relative increase in usual weekly earnings.

Table 4. Characteristics of Teenagers in California and Comparisons Areas, 1987 and 1989 (Standard Errors in Parentheses)

\begin{tabular}{|c|c|c|c|c|c|}
\hline \multirow[b]{2}{*}{ Characteristic } & \multicolumn{2}{|c|}{ California Teens } & \multicolumn{2}{|c|}{ Comparison Teens } & \multirow{2}{*}{$\begin{array}{c}\text { Difference in } \\
\text { Differences }\end{array}$} \\
\hline & 1987 & 1989 & 1987 & 1989 & \\
\hline $\begin{array}{l}\text { Percent with Wage } \\
\$ 3.35-4.24\end{array}$ & $\begin{array}{l}52.0 \\
(1.8)\end{array}$ & $\begin{array}{c}8.5 \\
(1.1)\end{array}$ & $\begin{array}{l}55.3 \\
(1.6)\end{array}$ & $\begin{array}{l}48.1 \\
(1.6)\end{array}$ & $\begin{array}{r}-36.5 \\
(3.1)\end{array}$ \\
\hline $\begin{array}{l}\text { Percent with Wage } \\
\quad=\$ 3.35\end{array}$ & $\begin{array}{l}15.5 \\
(1.3)\end{array}$ & $\begin{array}{c}0.7 \\
(0.3)\end{array}$ & $\begin{array}{l}16.1 \\
(1.2)\end{array}$ & $\begin{array}{l}11.3 \\
(1.0)\end{array}$ & $\begin{array}{r}-10.1 \\
(2.1)\end{array}$ \\
\hline $\begin{array}{l}\text { Percent with Wage } \\
\quad=\$ 4.25\end{array}$ & $\begin{array}{l}1.6 \\
(0.5)\end{array}$ & $\begin{array}{l}22.5 \\
(1.7)\end{array}$ & $\begin{array}{l}3.3 \\
(0.6)\end{array}$ & $\begin{array}{c}4.4 \\
(0.7)\end{array}$ & $\begin{array}{l}19.8 \\
(1.9)\end{array}$ \\
\hline Mean Log Wage & $\begin{array}{l}1.46 \\
(0.01)\end{array}$ & $\begin{array}{c}1.62 \\
(0.01)\end{array}$ & $\begin{array}{l}1.40 \\
(0.01)\end{array}$ & $\begin{array}{c}1.46 \\
(0.01)\end{array}$ & $\begin{array}{c}0.10 \\
(0.02)\end{array}$ \\
\hline $\begin{array}{l}\text { Variance of } \\
\text { Log Wages }\end{array}$ & $\begin{array}{c}0.109 \\
(0.010)\end{array}$ & $\begin{array}{c}0.109 \\
(0.015)\end{array}$ & $\begin{array}{c}0.086 \\
(0.008)\end{array}$ & $\begin{array}{c}0.090 \\
(0.009)\end{array}$ & $\begin{array}{c}-0.004 \\
(0.022)\end{array}$ \\
\hline $\begin{array}{l}\text { Usual Hours } \\
\text { per Week }\end{array}$ & $\begin{array}{l}26.2 \\
(0.4)\end{array}$ & $\begin{array}{l}26.7 \\
(0.5)\end{array}$ & $\begin{array}{c}27.9 \\
(0.4)\end{array}$ & $\begin{array}{l}28.1 \\
(0.4)\end{array}$ & $\begin{array}{c}0.3 \\
(0.8)\end{array}$ \\
\hline $\begin{array}{l}\text { Usual Earnings } \\
\text { per Week }(\$)\end{array}$ & $\begin{array}{r}125.6 \\
(3.5)\end{array}$ & $\begin{array}{r}149.8 \\
(4.3)\end{array}$ & $\begin{array}{r}121.3 \\
(2.4)\end{array}$ & $\begin{array}{c}132.1 \\
(2.6)\end{array}$ & $\begin{array}{c}13.4 \\
(6.6)\end{array}$ \\
\hline $\begin{array}{l}\text { Enrollment } \\
\text { Rate (\%) }\end{array}$ & $\begin{array}{c}66.5 \\
(1.0)\end{array}$ & $\begin{array}{l}63.1 \\
(1.3)\end{array}$ & $\begin{array}{c}57.2 \\
(1.0)\end{array}$ & $\begin{array}{c}59.2 \\
(1.0)\end{array}$ & $\begin{array}{l}-5.4 \\
(2.2)\end{array}$ \\
\hline $\begin{array}{l}\text { Employment } \\
\text { Rate }(\%)\end{array}$ & $\begin{array}{l}42.0 \\
(1.1)\end{array}$ & $\begin{array}{c}47.4 \\
(1.3)\end{array}$ & $\begin{array}{l}46.4 \\
(1.0)\end{array}$ & $\begin{array}{l}46.1 \\
(1.1)\end{array}$ & $\begin{array}{c}5.6 \\
(2.3)\end{array}$ \\
\hline $\begin{array}{l}\text { Labor Force } \\
\text { Part. Rate (\%) }\end{array}$ & $\begin{array}{l}50.5 \\
(1.1)\end{array}$ & $\begin{array}{l}54.2 \\
(1.3)\end{array}$ & $\begin{array}{l}56.9 \\
(1.0)\end{array}$ & $\begin{array}{l}54.8 \\
(1.1)\end{array}$ & $\begin{array}{c}5.9 \\
(2.3)\end{array}$ \\
\hline $\begin{array}{l}\text { Unemployment } \\
\text { Rate }(\%)\end{array}$ & $\begin{array}{l}16.7 \\
(1.2)\end{array}$ & $\begin{array}{l}12.6 \\
(1.2)\end{array}$ & $\begin{array}{l}18.5 \\
(1.1)\end{array}$ & $\begin{array}{l}15.9 \\
(1.1)\end{array}$ & $\begin{array}{r}-1.5 \\
(2.3)\end{array}$ \\
\hline $\begin{array}{l}\text { Employment Rate } \\
\text { of Enrollees }{ }^{\mathbf{b}}(\%)\end{array}$ & $\begin{array}{c}34.2 \\
(1.3)\end{array}$ & $\begin{array}{l}39.2 \\
(1.6)\end{array}$ & $\begin{array}{c}37.0 \\
(1.3)\end{array}$ & $\begin{array}{c}36.5 \\
(1.3)\end{array}$ & $\begin{array}{c}5.5 \\
(2.8)\end{array}$ \\
\hline Sample Size & 2,032 & 1,381 & 2,354 & 2,206 & - \\
\hline
\end{tabular}

Note: Samples include all individuals age 16-19.

${ }^{a}$ Change in outcome between 1989 and 1987 for California teens minus corresponding change for comparison area teens.

${ }^{\mathrm{b}}$ Employment rate among teenagers enrolled in school. 
As shown in Tables 2 and 3, these wage and earnings increases were accompanied by an increase in teenage employmentpopulation ratios. Most of this increased employment represented a net addition to the labor force: teenage unemployment rates registered only a small net decline.

The relative changes in employment between California and the comparison states are further illustrated in Figure 2, which plots quarterly employment rates from 1987 to 1989 for the two groups of teenagers. Employment rates were uniformly higher for the comparison group in 1987. Starting in 1988, however, the rates are much closer together. Because of the relatively large sampling errors and the volatility of the measured rates, it is difficult to identify a clear "turning point." There is no evidence, however, of the $3 \%$ to $8 \%$ decline in employment predicted by the estimates in Brown, Gilroy, and Kohen (1982) or Neumark and Wascher (1992).

A broader perspective on the change in employment for California teenagers is provided by Figure 3, which plots 1989 teenage employment-population ratios for all 50 states against their corresponding rates in 1987. (These data are taken from the same published source as the data in Table 2.) I have highlighted the California data as well as the data for other states that raised their minimum wage rates between 1987 and 1989. The average employmentpopulation ratio increased $2 \%$ across all states, compared with an increase of $4.1 \%$ in California and no net change in the comparison areas. These figures suggest that the narrower comparison of teenagers in California with those in Arizona, Florida, Georgia, New Mexico, and Dallas-Fort Worth may somewhat overstate the relative increase in the teenage employment rate in California. Whatever the comparison group, however, there is no apparent decline in employment among California teenagers.

A long-standing question in the minimum wage literature is whether changes in the minimum wage affect teenage school enrollment patterns (see, for example, Ehrenberg and Marcus 1980). The difference-in-differences in Table 4 suggests that relative enrollment rates fell in

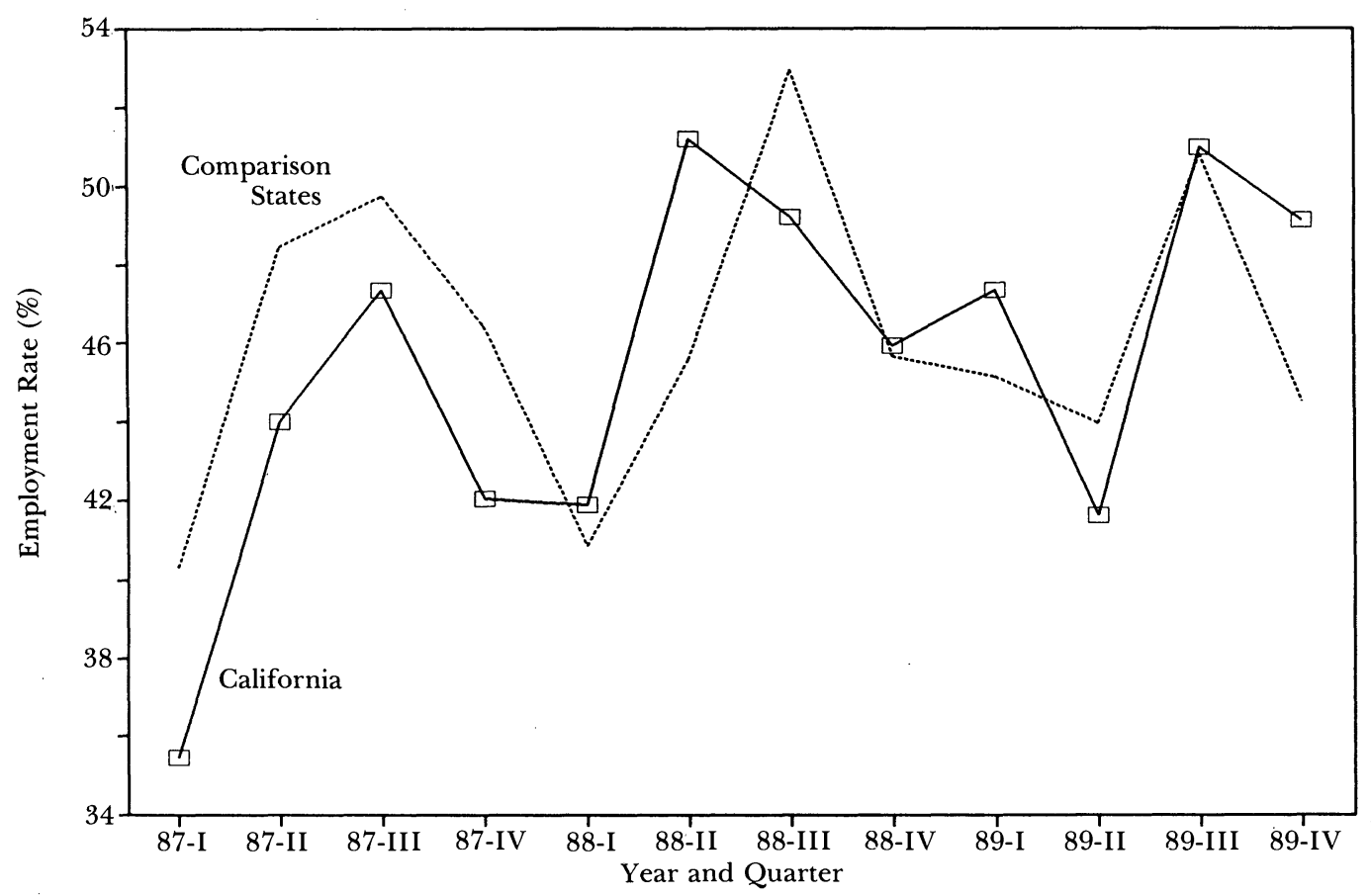

Figure 2. Teenage Employment Rates in California and Comparison States, 1987-1989. 


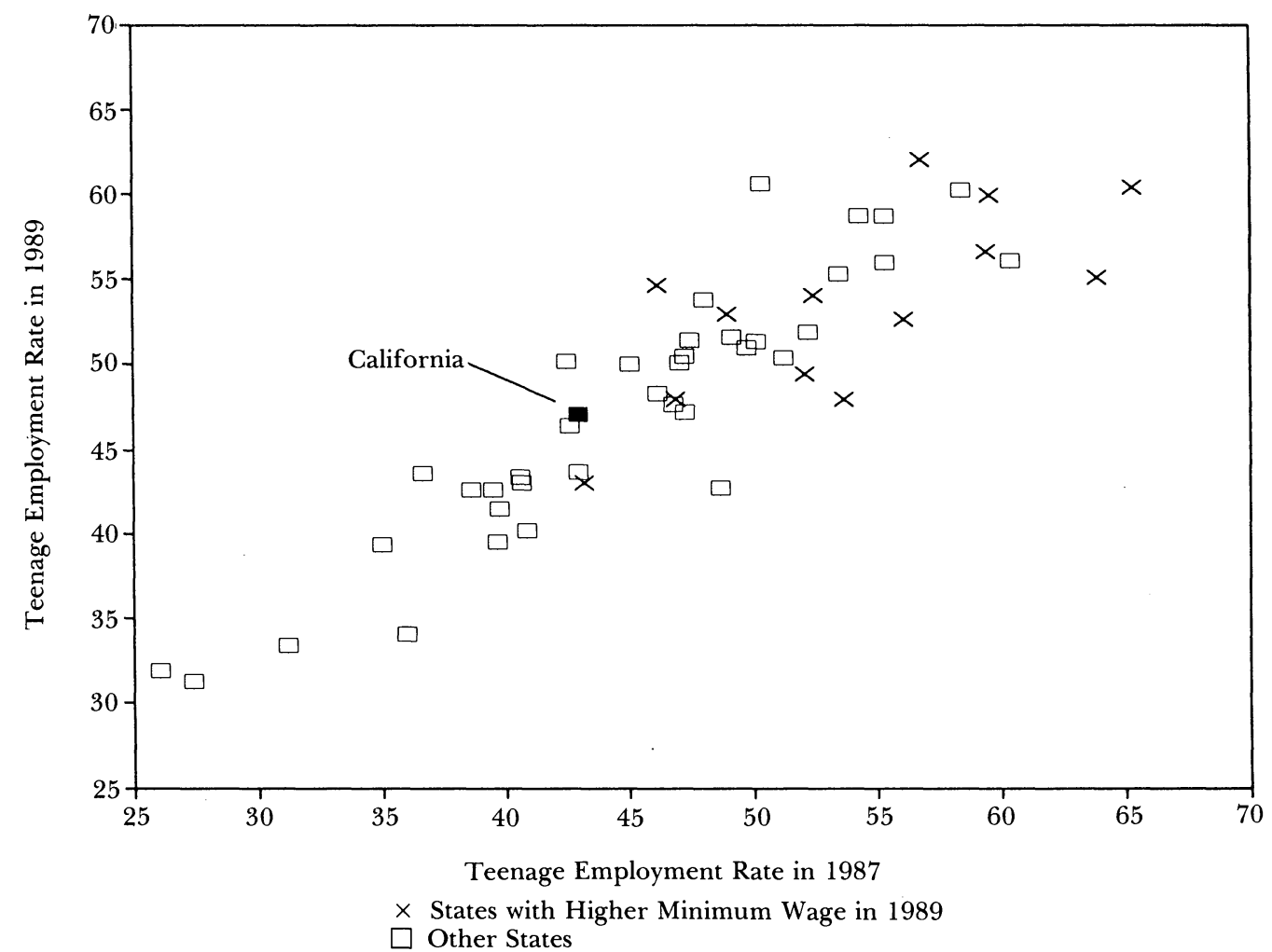

Figure 3. Teenage Employment-Population Rates in the 50 States and the District of Columbia: 1989 Rates Plotted Against 1987 Rates.

California after the rise in the minimum wage. Interestingly, these enrollment changes were not directly associated with the relative growth in California employment. Indeed, as shown in the penultimate row of the table, the relative increase in employment rates among enrolled students was about as large as the overall increase.

The enrollment measures in Table 4 are based on averages over all 12 months of the year, and therefore combine traditional school attendance, summer school, and other programs. A more conventional procedure is to measure enrollment in the fall: a difference-in-differences in enrollment rates from September to December shows a slightly smaller relative decline in California ( $-3.8 \%$, with a standard error of 4.0). Although imprecisely estimated, this effect is still relatively large. To check the magnitude of the enrollment change, I collected administrative data on high school and college enrollment in California and the comparison states over the 1987-89 period. Combining public high school enrollment and total undergraduate enrollment in all types of higher education, California enrollment fell 2 percentage points between fall 1987 and fall 1989.11 Similar enrollment measures in the comparison states rose 1.3 percentage points. This divergence is roughly consistent with the patterns in Table 4.12

The simple means and differences in

${ }^{11}$ The data on public high school enrollment are from U.S. Department of Education, Digest of Education Statistics 1991, Table 39. The undergraduate enrollment data are from the same source, Table 185.

${ }^{12}$ Changes in total enrollment and enrollment rates are only strictly comparable if population growth rates are similar. Data in U.S. Bureau of the Census (1990) show slightly faster population growth for individuals age 15-24 in California than in the comparison states over the 1987-89 period. 
Table 4 make no adjustment for the demographic characteristics of the teenagers actually sampled in the CPS. Although in principle the CPS sample is representative of the population, it is possible that adjustments for measured characteristics such as age, gender, and ethnicity could lead to more stable and precise estimates of the relative changes between California and the comparison states. These adjustments are easily accomplished in a regression framework by pooling the samples for California and the comparison areas in the two years, and including various control variables as well as indicators for the four underlying samples.

Using that procedure, I measured the relative changes in employment probabilities, wages, and enrollment probabilities between 1987 and 1989, controlling for age (four single age categories), gender, ethnicity (four categories), month of the sample, and location (indicators for four major cities in California and the individual states in the comparison sample). Controlling for these characteristics, the relative changes in the employment rate and the mean log wage rate are essentially identical to the unadjusted differences-indifferences. (The regression-adjusted standard errors are also very similar to the unadjusted standard errors in Table 4.) The implied relative change in the enrollment rate is $-3.1 \%$, slightly smaller than the unadjusted difference-in-differences and comparable to the relative change in fall enrollments. On balance, the addition of control variables does not affect the conclusions in Table 4.

The data in Table 4 also make no distinction between individuals age 18 and 19 , who are legally covered by the $\$ 4.25$ minimum wage in California, and individuals age 16 and 17 , who are covered by a $\$ 3.60$ youth subminimum. If employers can hire 16- and 17-year-olds for $\$ 3.60$, and must pay $\$ 4.25$ for workers over age 18 , it is conceivable that the rise in the minimum generated a shift in demand away from older teenage workers and in favor of younger ones.

To check that possibility, I computed the means for 16-17-year-olds and 18-19- year-olds separately. The differences-indifferences of log wages and employment rates show a larger relative wage gain for the younger teens $(15 \%$, versus $6 \%$ for 18-19-year-olds) and smaller relative employment growth (3 percentage points, versus 7 ). Although these results rule out any widespread substitution of younger for older teenagers, it should be noted that the youth subminimum wage is apparently only rarely used. There is no evidence of a spike in the wage distribution of 16-17-year-olds in California at the subminimum, nor was there a much higher fraction of 16-17-year-olds than of 18-19-year-olds earning less than $\$ 4.25$ per hour in 1989. Despite the legal provision of a youth subminimum wage, labor market participants seem to view the adult minimum as the relevant one for all workers. ${ }^{13}$

\section{Effects on Retail Trade}

Almost one-half of California workers whose 1987 wage rates were between the old federal minimum and the new state minimum were employed in retail trade. The experiences of retail trade are especially interesting because the Industrial Wage Commission initially set a subminimum for tipped employees in the restaurant industry. This provision was later overruled, leaving the state with a $20 \%$ higher-than-intended minimum in a large sector of the retail industry. One might expect the adverse consequences of an unintended age floor to be larger than the effects of a deliberately chosen rate.

Table 5 summarizes the characteristics of retail trade employees in California and the comparison sample in 1987 and 1989. There was a substantial relative reduction in the fraction of California workers earning between $\$ 3.35$ and $\$ 4.24$ after the new minimum wage took effect. This change was associated with a $5-7 \%$ relative increase in hourly and weekly earnings

\footnotetext{
${ }^{13} \mathrm{Katz}$ and Krueger (1990) present survey evidence for the fast-food industry in Texas that suggests that only $3 \%$ of employers use the subminimum provision of the federal law.
} 
Table 5. Characteristics of Workers in Retail Trade: California and Comparison Areas, 1987 and 1989.

(Standard Errors in Parentheses)

\begin{tabular}{|c|c|c|c|c|c|}
\hline \multirow[b]{2}{*}{ Characteristic } & \multicolumn{2}{|c|}{ California } & \multicolumn{2}{|c|}{ Comparison Areas } & \multirow{2}{*}{$\begin{array}{l}\text { Difference in } \\
\text { Differences }^{\mathrm{a}}\end{array}$} \\
\hline & 1987 & 1989 & 1987 & 1989 & \\
\hline \multicolumn{6}{|c|}{ Percentage of Workers with: } \\
\hline Wage $<\$ 3.35$ & $\begin{array}{c}1.7 \\
(0.3)\end{array}$ & $\begin{array}{c}1.2 \\
(0.3)\end{array}$ & $\begin{array}{c}7.1 \\
(0.5)\end{array}$ & $\begin{array}{c}6.6 \\
(0.5)\end{array}$ & $\begin{array}{c}-0.1 \\
(0.8)\end{array}$ \\
\hline Wage $=\$ 3.35$ & $\begin{array}{l}10.6 \\
(0.7)\end{array}$ & $\begin{array}{c}0.7 \\
(0.2)\end{array}$ & $\begin{array}{c}7.1 \\
(0.5)\end{array}$ & $\begin{array}{c}4.7 \\
(0.4)\end{array}$ & $\begin{array}{r}-7.6 \\
(1.0)\end{array}$ \\
\hline $\begin{array}{l}\text { Wage Between } \\
\$ 3.35 \text { and } \$ 4.24\end{array}$ & $\begin{array}{l}30.8 \\
(1.1)\end{array}$ & $\begin{array}{c}4.7 \\
(0.5)\end{array}$ & $\begin{array}{l}30.1 \\
(0.9)\end{array}$ & $\begin{array}{l}24.2 \\
(0.8)\end{array}$ & $\begin{array}{r}-20.2 \\
(1.7)\end{array}$ \\
\hline Wage $=\$ 4.25$ & $\begin{array}{c}0.8 \\
(0.2)\end{array}$ & $\begin{array}{l}14.7 \\
(0.9)\end{array}$ & $\begin{array}{c}1.7 \\
(0.3)\end{array}$ & $\begin{array}{c}2.8 \\
(0.3)\end{array}$ & $\begin{array}{c}12.7 \\
(1.0)\end{array}$ \\
\hline \multicolumn{6}{|c|}{ Other Characteristics of Workers: } \\
\hline Mean Log Wage & $\begin{array}{c}1.80 \\
(0.01)\end{array}$ & $\begin{array}{c}1.90 \\
(0.01)\end{array}$ & $\begin{array}{c}1.67 \\
(0.01)\end{array}$ & $\begin{array}{c}1.72 \\
(0.01)\end{array}$ & $\begin{array}{c}0.05 \\
(0.02)\end{array}$ \\
\hline Usual Hours/Week & $\begin{array}{l}34.9 \\
(0.2)\end{array}$ & $\begin{array}{c}35.0 \\
(0.3)\end{array}$ & $\begin{array}{l}36.7 \\
(0.2)\end{array}$ & $\begin{array}{l}36.8 \\
(0.2)\end{array}$ & $\begin{array}{c}0.1 \\
(0.5)\end{array}$ \\
\hline $\begin{array}{l}\text { Usual Earnings/ } \\
\text { Week (\$) }\end{array}$ & $\begin{aligned} 261.1 \\
(5.0)\end{aligned}$ & $\begin{array}{l}291.2 \\
\quad(6.3)\end{array}$ & $\begin{array}{r}241.5 \\
(4.0)\end{array}$ & $\begin{array}{l}252.4 \\
(3.7)\end{array}$ & $\begin{array}{l}19.2 \\
(9.8)\end{array}$ \\
\hline Percent Age 16-19 & $\begin{array}{l}16.7 \\
(0.7)\end{array}$ & $\begin{array}{l}16.4 \\
(0.9)\end{array}$ & $\begin{array}{c}15.7 \\
(0.6)\end{array}$ & $\begin{array}{l}16.1 \\
(0.6)\end{array}$ & $\begin{array}{c}-0.7 \\
(1.4)\end{array}$ \\
\hline Percent Age 20-24 & $\begin{array}{l}19.6 \\
(0.8)\end{array}$ & $\begin{array}{l}19.0 \\
(0.9)\end{array}$ & $\begin{array}{l}18.1 \\
(0.7)\end{array}$ & $\begin{array}{l}17.4 \\
(0.6)\end{array}$ & $\begin{array}{c}0.1 \\
(1.5)\end{array}$ \\
\hline $\begin{array}{l}\text { Percent Age 16-24 } \\
\text { \& in School }\end{array}$ & $\begin{array}{l}14.9 \\
(0.7)\end{array}$ & $\begin{array}{l}15.7 \\
(0.8)\end{array}$ & $\begin{array}{l}12.7 \\
(0.6)\end{array}$ & $\begin{array}{l}12.5 \\
(0.6)\end{array}$ & $\begin{array}{c}1.0 \\
(1.4)\end{array}$ \\
\hline Percent Female & $\begin{array}{l}49.2 \\
(1.0)\end{array}$ & $\begin{array}{l}46.4 \\
(1.1)\end{array}$ & $\begin{array}{l}51.0 \\
(0.9)\end{array}$ & $\begin{array}{l}49.9 \\
(0.9)\end{array}$ & $\begin{array}{l}-1.6 \\
(1.9)\end{array}$ \\
\hline Percent Hispanic & $\begin{array}{l}20.6 \\
(0.8)\end{array}$ & $\begin{array}{l}24.9 \\
(1.0)\end{array}$ & $\begin{array}{l}11.9 \\
(0.6)\end{array}$ & $\begin{array}{l}11.6 \\
(0.6)\end{array}$ & $\begin{array}{c}4.5 \\
(1.5)\end{array}$ \\
\hline Sample Size & 2,521 & 1,889 & 3,394 & 3,388 & - \\
\hline
\end{tabular}

Note: Samples include individuals age $16-68$ employed in retail trade industry.

${ }^{a}$ Change in outcome between 1989 and 1987 for California workers minus corresponding change for comparison workers.

among California workers. There were no corresponding changes in weekly hours or in the age or gender composition of retail employment. The one significant relative demographic change is an increase in the fraction of Hispanic workers in California retailing. Contrary to expectations, none of these comparisons suggest a substitution away from less-skilled workers.

I have also computed the same comparisons for employees of eating and drinking establishments. These workers constitute $30 \%$ of all employees in retail trade and $50 \%$ of those who earned between $\$ 3.35$ and $\$ 4.24$ in 1987 . The comparisons show a 42 percentage point relative decline in the fraction of restaurant workers earning between $\$ 3.35$ and $\$ 4.24$ per hour, a 31 percentage point relative increase in the fraction earning exactly $\$ 4.25$ per hour, and an $8 \%$ relative increase in mean log wages. As for the entire retail trade industry, there is no indication of skill-upgrading, at least as measured by changes in the age, gender, or ethnic composition of the work force for eating and drinking establishments.

The CPS microdata show significant relative wage gains for retail trade and restaurant workers following the rise in the California minimum wage. To measure any corresponding changes in employment, I have assembled establishment-level data from the unemployment insurance system in Table 6. One minor difficulty with these data is that employ- 
Table 6. Employment in Retail Trade and Eating and Drinking, California, Comparison Areas, and the Entire Country, 1984-90.

\begin{tabular}{lccccccc}
\hline & \multicolumn{7}{c}{ Employment Relative to 1985-87 Average: } \\
\cline { 2 - 8 } Sample & 1984 & 1985 & 1986 & 1987 & 1988 & 1989 & 1990 \\
\hline All Retail Trade: & & & & & & & \\
California & 0.93 & 0.97 & 1.00 & 1.03 & 1.07 & 1.10 & 1.11 \\
Comparisons & 0.92 & 0.97 & 1.00 & 1.03 & 1.05 & 1.09 & 1.10 \\
All U.S. & 0.93 & 0.97 & 1.00 & 1.03 & 1.06 & 1.09 & 1.10 \\
Eating and Drinking Establishments: & & & & & & \\
California & 0.92 & 0.97 & 1.00 & 1.04 & 1.07 & 1.08 & 1.10 \\
Comparisons & 0.90 & 0.96 & 1.00 & 1.04 & 1.07 & 1.10 & 1.14 \\
All U.S. & 0.92 & 0.97 & 1.00 & 1.04 & 1.07 & 1.09 & 1.11 \\
\hline \multicolumn{1}{l}{ Notes: In this }
\end{tabular}

Notes: In this table only, the comparison areas are Arizona, Florida, Georgia, New Mexico, and all of Texas. Data are from U.S. Department of Labor, Bureau of Labor Statistics, "Employment and Wages-Annual Averages," 1984-1990 editions.

ment counts for Dallas-Fort Worth are unavailable. In this table the comparison sample therefore includes all of Texas.

For retail trade as a whole, the establishment-level data show very similar trends in employment growth in California and the comparison areas between 1984 and 1987. This pattern continues after 1988, with slightly stronger employment growth in California between 1987 and 1989. For eating and drinking establishments, the 1984-88 data suggest a stronger trend in employment growth in the comparison states than in California or the country as a whole. From 1987 to 1989 employment growth in California was 2.0 percentage points lower than in the comparison sample, and 1 percentage point lower than in the United States. Taking account of the stronger growth rate in eating and drinking employment in the comparison states before 1988, the 1987-89 data suggest a 1 percentage point relative employment loss in California. This finding may reflect an adverse effect of the minimum wage, but given the absence of any effects for retail trade as a whole or for low-wage demographic groups, it may instead simply reflect longer-run trends.

The retail trade industry, and eating and drinking establishments in particular, are characterized by a relatively high fraction of unskilled labor input. In light of the wage increases generated by the rise in the minimum wage, it is interesting to examine some industry price data. Figure 4 present 1987 and 1989 price indexes for 24 major cities on the cost of food away from home. The Bureau of Labor Statistics compiles the data for three California cities: Los Angeles, San Diego, and San Francisco. The figure also shows the fitted regression line that predicts the 1989 index for each city based on its 1987 value. The 1989 prices for Los Angeles and San Francisco are very close to their predicted values, given the pattern of price changes in other cities. Prices in San Diego, on the other hand, are some $5 \%$ higher than predicted.

This pattern coincides with a larger wage increase observed for San Diego teenagers than for teenagers elsewhere in the state. Unfortunately, the sample sizes for individual cities in the CPS are small, and some city-specific variation can be expected from the sample design of the CPS. Thus, it is very difficult to obtain reliable estimates of teenage wages by city. Although it may be tempting to attribute the San Diego price increases to the relatively larger wage increases there, the absence of a statewide pattern of increases for the price of food away from home is still a puzzle.

Some further evidence on restaurant prices is available from a survey conducted in over 250 cities nationwide by local affiliates of the American Chamber of Commerce Researchers Association (ACCRA). Among the prices collected by ACCRA are the prices of quarter-pound hamburgers. (See ACCRA, various years.) Data are available for seven California cities (Bakersfield, Fresno, Los Angeles, Riverside, Sacramento, San Diego, and 


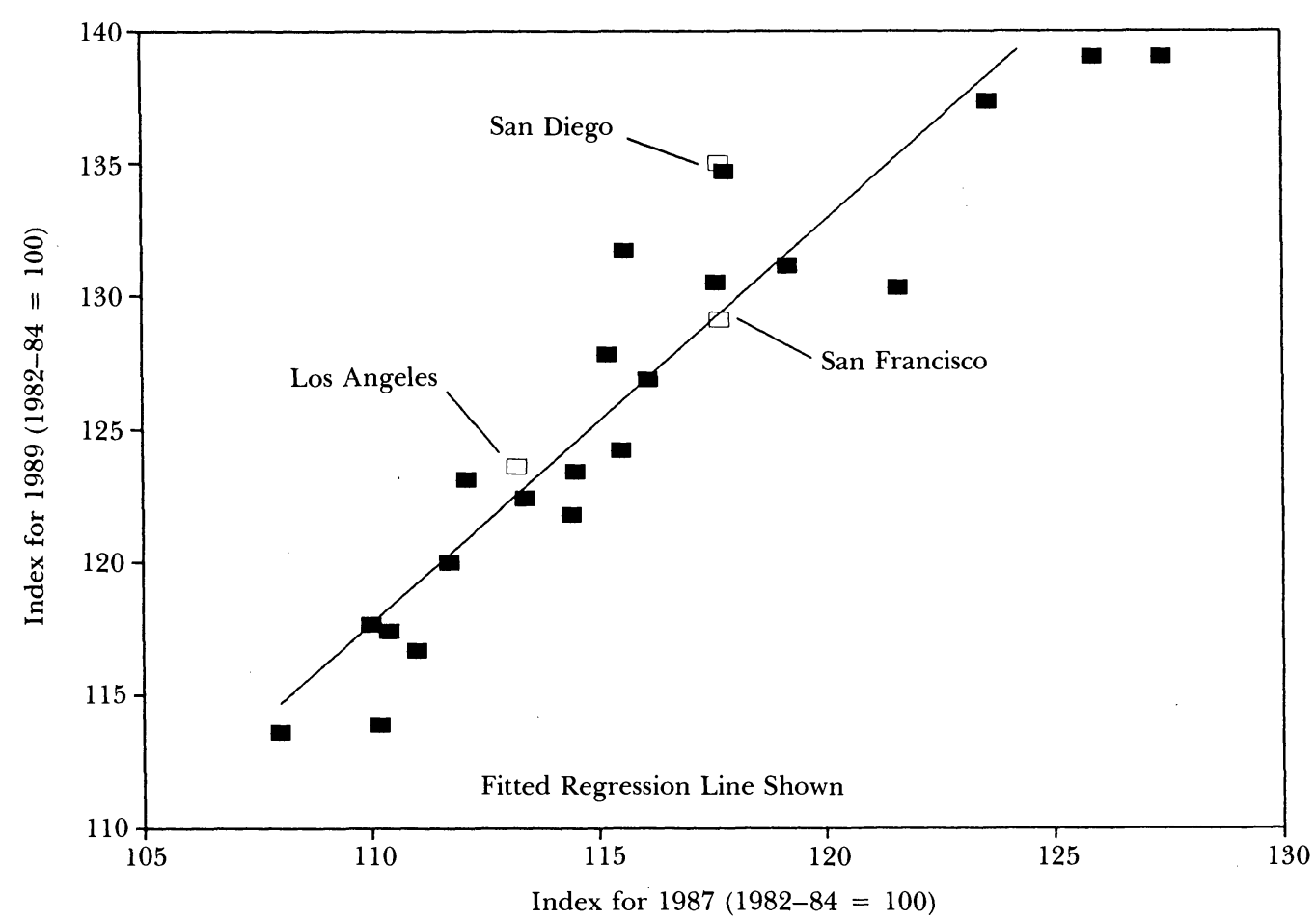

Figure 4. The Cost of Food Away from Home in 24 Major Cities: 1989 Index Plotted Against 1987 Index.

San Jose) and several cities in the comparison area (including Phoenix, Tucson, and Dallas). A comparison of the averages of quarterly prices for 1987 and 1989 shows that three California cities (Riverside, Sacramento, and San Diego) had slightly faster price growth than other cities in the ACCRA sample. The remaining California cities, and Phoenix, Tucson, and Dallas, all show little change relative to the all-cities average. Neither the BLS data nor the ACCRA data show a pattern of statewide increases in California restaurant prices between 1987 and 1989 .

\section{Interpretation of the Findings}

I find no empirical support for the conventional prediction that economists make regarding the employment effect of minimum wages. Although the rise in the minimum wage in California raised the earnings of low-wage workers, it does not seem to have significantly reduced employment, even in the retail trade indus- try. For teenagers the changes following the rise in the minimum wage are particularly striking: hourly and weekly earnings rose by $10 \%$ while the employmentpopulation ratio rose by $4 \%$. The observed employment changes contrast with predictions based on aggregate time series studies, which imply a $3-8 \%$ reduction in teenage employment following a $27 \%$ increase in the minimum wage.

These findings are inconsistent with a conventional competitive model of the lowwage labor market. An alternative model that is often suggested in theoretical discussions of the minimum wage is one in which employers of low-wage workers have market power and act as monopsonistic purchasers of labor (see, for example, Stigler 1946). In this model the imposition of a binding wage floor can lead to an increase in wages, an increase in employment, an increase in industry output, and a reduction in industry selling prices. In my opinion, the experiences following the rise in the California minimum wage suggest that this 
model or other alternative models deserve more careful scrutiny.

Whether a monopsonistic model provides the correct interpretation of events in the labor market for California teenagers between 1987 and 1989 is of obvious importance for economists' interpretation of labor market behavior and policy. Economists have been reluctant to admit the possibility of market power in the labor market, owing to the mobility of workers and to the fact that most labor markets involve large numbers of relatively small employers. ${ }^{14}$ It seems unlikely that a monopsonistic outcome arises from the market power of an individual employer. Nevertheless, when teenage workers are asked what wage rate they would require to move to a similar job in the same area, they name a wage $26 \%$ higher than their current wage. ${ }^{15}$ This

\footnotetext{
${ }^{14}$ One exception is the market for highly specialized labor in a particular geographic location. Sullivan (1989) examines the market for registered nurses and finds evidence of exploitable market power at the hospital level. Ransom (1990) examines the market for academic faculty and interprets the negative relation between wages and length of service as a monopsony effect.

${ }^{15}$ This estimate is derived from a sample of 1,028 employed teenagers in the 1982 wave of the National Longitudinal Survey of Youth who report a hypo-
}

fact suggests that low-wage employers may enjoy some degree of monopsony power.

An alternative view is that the California labor market was "trapped" in an equilibrium with excess demand for labor-perhaps because employers had historically viewed the federal minimum as a binding wage floor and failed to adjust to the decline in its real value over the 1980s. Given the low wages paid by other firms, and a general shortage of labor, no individual employer had an incentive to offer a (marginally) higher wage to recruit new workers. Employers continued to post vacancies, however, and continued trying to recruit new workers without raising the wages of their existing work force.

More research will be needed before economists embrace non-competitive models of the labor market. In the meantime, evidence from the study of California's experiences should temper any confident assessment of the welfare economics of minimum wages.

thetical hourly wage required to move to a similar job at a different employer. The standard error on the estimated premium is 0.01 .

Appendix

Characteristics of California and Comparison Samples, 1987

\begin{tabular}{lcr}
\hline Characteristic & California & Comparisons \\
\hline Mean Age & 37.5 & 38.3 \\
Percent Female & 50.9 & 51.5 \\
Percent Age 16-19 & 8.7 & 8.7 \\
Average Education (Years) & 12.6 & 12.4 \\
Percent College Grads & 21.4 & 17.7 \\
Percent White Non-Hispanic & 63.1 & 70.7 \\
Percent Black Non-Hispanic & 6.7 & 15.5 \\
Percent Hispanic & 21.2 & 11.7 \\
Percent Asian and Other Non-Hispanic & 8.9 & 1.9 \\
Percent Married & 55.5 & 58.0 \\
Percent in Central City & 37.0 & 26.8 \\
Percent Union Members & 19.5 & 7.8 \\
Percent Government Wkrs. & 13.6 & 13.6 \\
Percent Self-Employed & 8.5 & 6.9 \\
Mean Wage $\$$ /Hour) & 10.69 & 8.77
\end{tabular}


Appendix (Continued)

\begin{tabular}{lrr}
\hline Characteristic & California & Comparisons \\
\hline Industry Disbribution: & 3.4 & 2.7 \\
Agriculture & 10.3 & 12.3 \\
Construction & 14.4 & 10.4 \\
Manufacturing & 6.6 & 7.3 \\
Transportation, Communication, Utilities & 23.1 & 25.2 \\
Trade & 7.2 & 7.4 \\
Finance, Insurance, Real Estate & 34.0 & 32.8 \\
Services & & . \\
\hline
\end{tabular}

\section{REFERENCES}

American Chamber of Commerce Researchers Association. Various years. "Cost of Living Index." Louisville, Ky.: American Chamber of Commerce Researchers Association.

Ashenfelter, Orley, and Robert Smith. 1979. "Compliance with the Minimum Wage Law." Journal of Political Economy, Vol. 87, No. 2 (April), pp. 222-350.

Brown, Charles, Curtis Gilroy, and Andrew Kohen. 1982. "The Effect of the Minimum Wage on Employment and Unemployment." Journal of Economic Literature, Vol. 20, No. 2 (June), pp. $487-528$

1983. "Time Series Evidence on the Effect of the Minimum Wage on Youth Employment and Unemployment." Journal of Human Resources, Vol. 18, No. 2 (Winter), pp. 3-31.

Card, David. 1991. "Do Minimum Wages Reduce Employment? A Case Study of California, 198789." National Bureau of Economic Research Working Paper Number 3710. Cambridge, Mass.: NBER.

1992. "Using Regional Variation in Wages to Measure the Effects of the Federal Minimum Wage." Industrial and Labor Relations Review, Vol. 46, No. 1 (October), pp. 22-37.

Ehrenberg, Ronald, and Alan J. Marcus. 1980. "Minimum Wage Legislation and the Educational Outcomes of Youth." In Ronald Ehrenberg, ed., Research in Labor Economics, Vol. 3. Greenwich, Conn.: JAI Press, pp. 61-93.

Gramlich, Edward. 1976. "Impact of Minimum Wages on Other Wages, Employment, and Family Income." Brookings Papers on Economic Activity, No. 2, pp. 409-51.

Grossman, Jean B. 1983. "The Impact of the Minimum Wage on Other Wages." Journal of Human Resources, Vol. 18, No. 3 (Summer), pp. 359-78.

Katz, Lawrence F., and Alan B. Krueger. 1990. "The Effects of the New Minimum Wage in a Low-Wage
Labor Market." Proceedings of the Forty-Third Annual Meeting (December 28-29, 1990). Madison, Wis.: Industrial Relations Research Association, pp. 254-65.

Lester, Richard A. 1946. "Shortcomings of Marginal Analysis for Wage-Employment Problems." American Economic Review, Vol. 36, No. 1 (March), pp. $63-82$.

Neumark, David, and William Wascher. 1992 "Employment Effects of Minimum and Subminimum Wages: Panel Data on State Laws." Industrial and Labor Relations Review, Vol. 46, No. 1 (October), pp. 55-81.

Questor, Aline O. 1981. "State Minimum Wage Laws, 1950-1980." In Report of the Minimum Wage Study Commission, Vol. 2. Washington, D.C.: GPO.

Ransom, Michael. 1990. "Monopsony in the Academic Labor Market." Unpublished paper, Brigham Young University Department of Economics.

Stigler, George. 1946. "The Economics of Minimum Wage Legislation." American Economic Review, Vol. 36, No. 3 (June), pp. 358-65.

Sullivan, Daniel G. 1989. "Monopsony Power in the Market for Nurses." Journal of Law and Economics, Vol. 32, No. 2 (October, part 2), pp. S135-S178.

U.S. Bureau of the Census. 1990. "State Population and Household Estimates: July 1, 1989." Series P-25, No. 1058. Washington, D.C.: GPO.

U.S. Bureau of Labor Statistics. Various years. "Geographic Profiles of Employment and Unemployment." Washington, D.C.: GPO.

U.S. Department of Education, Office of Educational Research and Research Improvement. 1991. "Digest of Education Statistics 1991." Washington, D.C.: GPO.

Welch, Finis. 1976. "Minimum Wage Legislation in the United States." In Orley Ashenfelter and James Blum, eds., Evaluating the Labor Marke Effects of Social Programs. Princeton, N.J.: Princeton University, Industrial Relations Section. 